\title{
The Influence of the Metal Mesh to the Attachment Manner of CFRP Wind Turbine Blades
}

\author{
Zixin Guo ${ }^{1}$, Wanshui $\mathrm{Yu}^{1}$, Zhiyang Fang ${ }^{2}$, Minhao Zhang ${ }^{1}$, Hongbo $\mathrm{Li}^{1}$, Qingmin $\mathrm{Li}^{1}$, Wah Hoon Siew ${ }^{3}$ \\ 1. State Key Lab of Alternate Electrical Power System with Renewable Energy Sources, North China Electric Power University, \\ Beijing, China. \\ 2. Sinoma Wind Power Blade Co., Ltd., Beijing, China. \\ 3. Department of Electronic and Electrical Engineering, University of Strathclyde, Glasgow, U.K.
}

\begin{abstract}
Wind turbine blade with carbon fiber reinforced plastics (CFRP) beam has much better mechanism performance. However, it faces the severe problem of lightning protection due to the conductivity of CFRP. Metal mesh are installed on CFRP blades by many manufacturers in order to protect the main beam. The performance of the metal mesh was not fully tested with real blade tip. In this paper, the blade tip equipped with tip receptor and fully covered mesh are tested under both negative and positive switching impulses. The results show that the mesh has little influence on the attachment manner. The results between nonemesh GFRP and with-mesh CFRP blade is also compared.
\end{abstract}

Keywords-lightning protection system; wind turbine blade; attachment process; CFRP

\section{INTRODUCTION}

The carbon fiber reinforced plastics (CFRP) is the next generation material for the beam of wind turbine (WT) blade, especially for the offshore wind farms. CFRP has much better mechanism performance compared with glass fiber reinforced plastics (GFPR). However, it has a fatal problem for the aspect of lightning protection. The CFRP beam can be regards as external conductor through the whole blade, which may cause it, hit by the lightning strikes directly, be damaged.

Most of MW wind turbine blades are equipped with one tip receptor and several side receptors along the blade tip $(\sim 10 \mathrm{~m})$, as shown in Fig. 1 (a). In order to eliminate the risk of interception failure for CFRP WT blade, some of the blade manufacturers install metal mesh over the blade beam or cover the whole blade tip (Fig. 1 (b) \& (c)).

Several experimental researches have been done to investigate the performance of different kinds of receptors [1] [7]. The tip receptor can provide good protection for $5 \mathrm{~m}$ GFRP blade tip under the simulated negative lightning strikes [7]. The testing results from Sinoma Wind Power Blade Co., Ltd also verify it. The thin metal mesh along the center of the blade has been tested by [6]. However, the performance under the combination of both tip receptor and metal mesh is still not clear. There are also few reports about the performance of fully covered mesh.

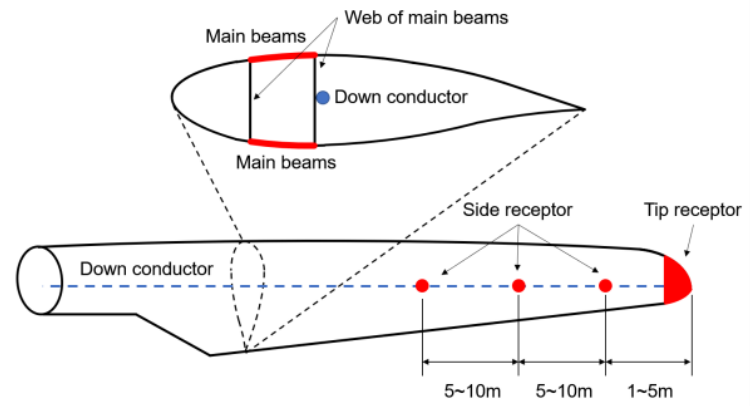

(a) The typical lightning protection system for the GFRP wind turbine blade

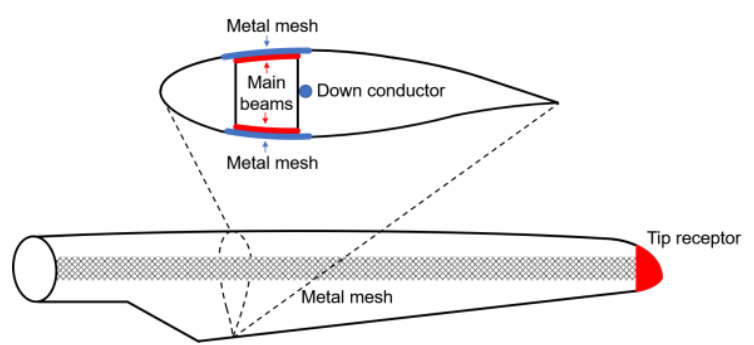

(b) The CFRP wind turbine blade equipped with metal mesh over the main beam

This work was supported by National Natural Science Foundation of China (51420105011). 


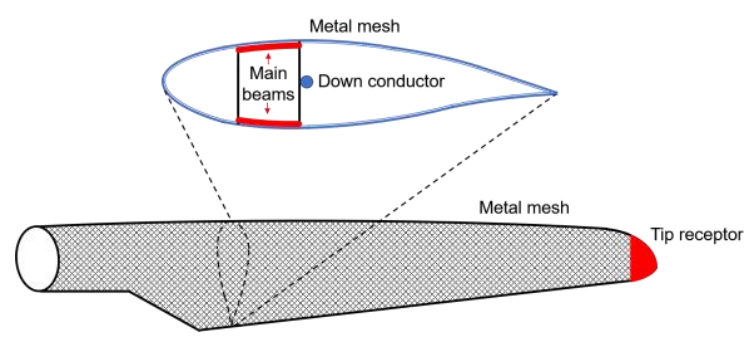

(c) The CFRP wind turbine blade equipped with metal mesh covering the whole blade

Figure 1. The lightning protection system of the MW wind turbine blade

In this paper, the influence of the metal mesh to the attachment manner of CFRP wind turbine blade is investigated by experiments. Both negative and positive switching impulses are used to simulate different polarities of cloud-to-ground flashes (CGs). The comparation of attachment points location is made between without-mesh GFRP and with-mesh CFRP blades.

\section{EXPERIMENTS}

\section{A. Specimen}

A $5.5 \mathrm{~m}$ CFRP blade tip specimen with aluminum tip receptor and covered with aluminum mesh is employed, as shown in Fig. 2. Both the receptor and mesh are grounded by 70 $\mathrm{mm}^{2}$ copper twisted wire inside blade chamber. The cross section of the specimen has the similar structure as shown in Fig. 1 (c), where the main beam and web end at about $3 \mathrm{~m}$ from the tip.

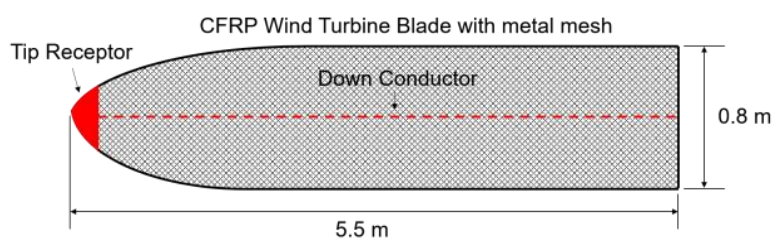

Figure 2. CFRP blade tip specimen with tip receptor and metal mesh

\section{B. Experiment setup}

A rod electrode is used to simulate the lightning downward leader (DL). Hereinafter, the leader propagating from rod electrode is called downward leader. The vertical length of the gap is $2.5 \mathrm{~m}$. two different lateral (LD) distances are tested, $0 \mathrm{~m}$ and $1.8 \mathrm{~m}$, respectively. The specimen is placed on a $1 \mathrm{~m}$ insulated supporter. The orientation of the specimen is set to $45^{\circ}$.
The reason why only $45^{\circ}$ is used is based on our previous experiment results that the tip receptor can intercept all the downward leaders under $90^{\circ}$ and $60^{\circ}$ with horizontal [7], [8]. The wind ward / lee ward side is set to face the ground in order to simulate the most serious condition when the mesh gets the maximum area exposed to the downward leader. The experiments are conducted under both negative and positive standard switching impulses. The setup is shown in Fig. 3. A high-speed camera and a digital camera are used to record the attachment process. The frame rate is $240601 \mathrm{fps}$ and the interval is $4.1 \mu \mathrm{s} /$ frame.

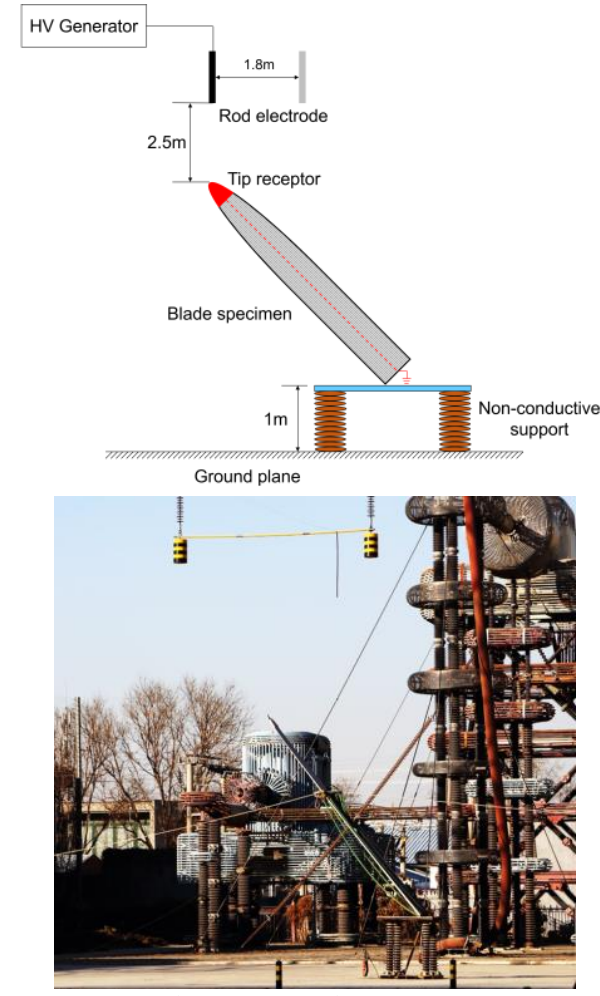

Figure 3. Experiment setup.

\section{RESULTS}

Both negative and positive tests are conducted for different LDs, each condition for 10 times, as shown in Table I (No. 1 4). The experiment results of GFRP blade from [7] are also shown in Table I (No. 5 - 8), for the comparison with/without metal mesh.

TABLE I THE LOCATION OF ATTACHMENT POINTS UNDER DIFFERENT CONDITIONS

\begin{tabular}{|c|c|c|c|c|c|c|c|c|c|}
\hline \multirow{2}{*}{ No. } & \multirow{2}{*}{$\begin{array}{l}\text { Type of } \\
\text { blade }\end{array}$} & \multirow{2}{*}{ Polarity } & \multirow{2}{*}{$\begin{array}{l}\text { Length of } \\
\text { gap }(\mathbf{m})\end{array}$} & \multirow{2}{*}{ Orientation } & \multirow{2}{*}{$\begin{array}{l}\text { LD } \\
\text { (m) }\end{array}$} & \multicolumn{3}{|c|}{ Location of attachment points } & \multirow{2}{*}{ Total } \\
\hline & & & & & & Tip receptor & The boundary of receptor and blade & Mesh & \\
\hline 1 & \multirow{4}{*}{$\begin{array}{l}\text { CFRP with } \\
\text { metal mesh }\end{array}$} & Negative & 2.5 & $45^{\circ}$ & 0 & 10 & 0 & 0 & 10 \\
\hline 2 & & Positive & 2.5 & $45^{\circ}$ & 0 & 9 & 1 & 0 & 10 \\
\hline 3 & & Negative & 2.5 & $45^{\circ}$ & 1.8 & 10 & 0 & 0 & 10 \\
\hline 4 & & Positive & 2.5 & $45^{\circ}$ & 1.8 & $5(5)$ & 4 & 1 & 10 \\
\hline 5 & \multirow{4}{*}{$\begin{array}{c}\text { GFRP } \\
\text { without } \\
\text { metal mesh }\end{array}$} & Negative & 3 & $90^{\circ}$ & 0 & 20 & 0 & - & 20 \\
\hline 6 & & Positive & 3 & $90^{\circ}$ & 0 & $20(1)$ & 0 & - & 20 \\
\hline 7 & & Negative & 1.5 & $30^{\circ}$ & 1.1 & $20(2)$ & 0 & - & 20 \\
\hline 8 & & Positive & 1.5 & $30^{\circ}$ & 1.1 & 0 & 10 & - & 10 \\
\hline
\end{tabular}

* The number in the bracket is the number of cases hit on the side of receptor. 


\section{A. The influence of the mesh under negative downward leader}

For negative condition, all the downward leaders are intercepted by tip receptor under different LDs (Table I No.1), which is similar to the results of no mesh GFRP blade (Table I No. $5 \&$ 7). There is no upward leader observed initiating from the mesh. The typical process is shown in Fig. 4 (a) \& (b). The mesh has no influence on the location of attachment point.

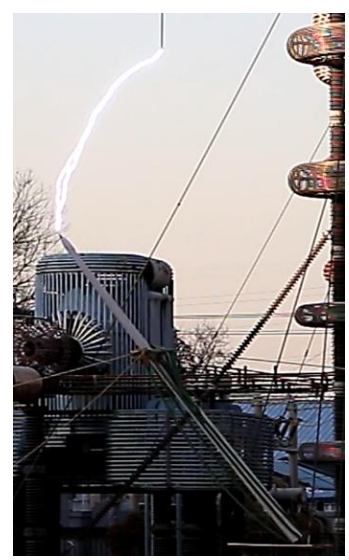

(a) The channel of the discharge under negative impulse.

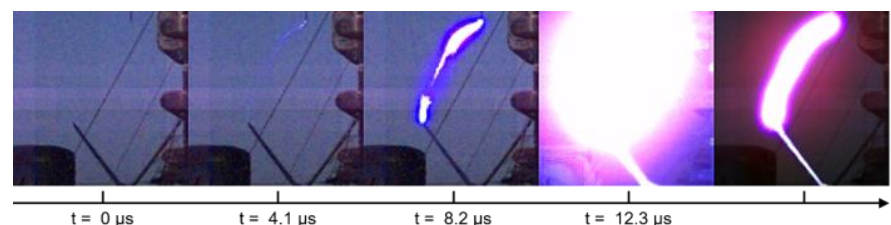

(b) The process of attachment process under negative impulse.

Figure 4. Observed results under negative impulse ( $L D=1.8 \mathrm{~m})$

\section{B. The influence under positive downward leader}

For positive condition, the attachment manners are different under different $\mathrm{LDs}$. When $\mathrm{LD}=0 \mathrm{~m}$, the results are similar to that under negative impulse.

When $\mathrm{LD}=1.8 \mathrm{~m}$, a strong shielding effect is observed. Most of the attachment points locate close to the boundary of the receptor and the blade, instead of the very tip of the receptor under the negative condition. About half of the cases the attachment points are on the receptor side and half on the edge of the receptor (Fig. 5 (a)).
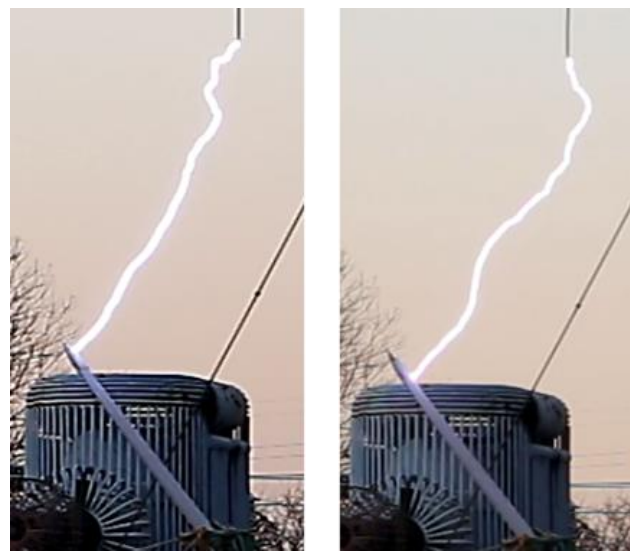

(a) Left: attachment point on the receptor side. Right: attachment point on the edge of the receptor.

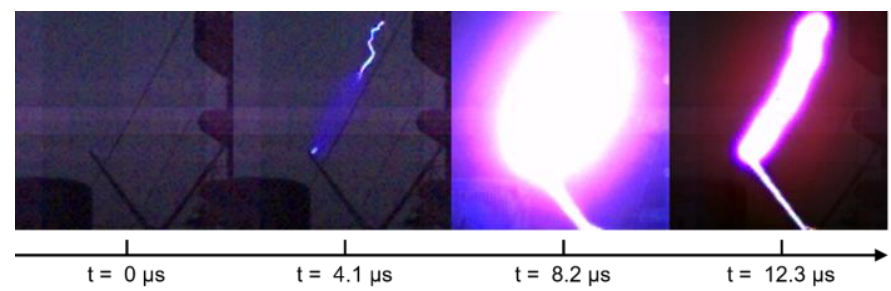

(b) The process of the attachment process under positive impulse.

Figure 5. Observed results under positive impulse $(\mathrm{LD}=1.8 \mathrm{~m})$

From all the cases that the receptor intercepts the downward leader successfully, it is observed that upward leader initiates from the receptor, no matter which part of it. However, in the case, which is the only one, that the DL hits on the metal mesh/blade surface far from the tip, no upward leader is observed from the mesh or the receptor, as shown in Fig. 6. It can be concluded that the interception failure is due to the ability of receptor to initiate upward leader is not strong enough. This can be also observed by rotation experiment of scale wind turbine model [9].

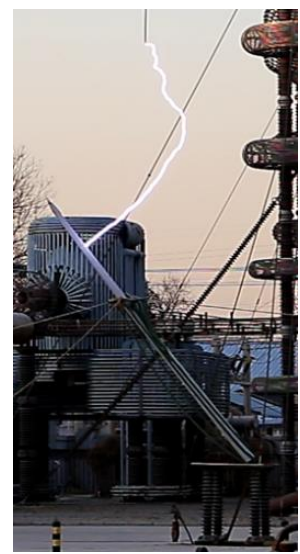

(a) The channel of the discharge under positive impulse.

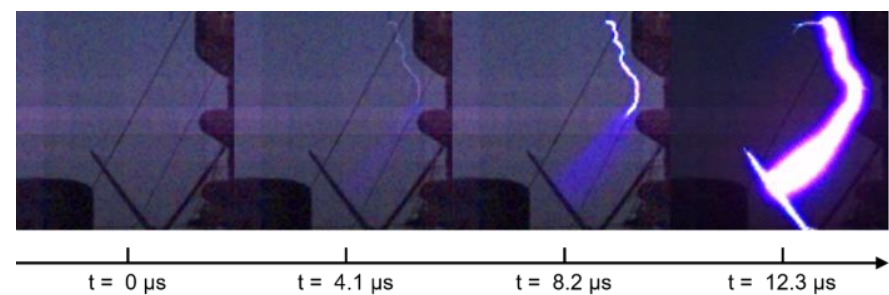

(b) The process of attachment process under positive impulse.

Figure 6. The case that downward leader hit on blade surface / metal mesh with no upward leader observed under positive impulse $(\mathrm{LD}=1.8 \mathrm{~m})$.

It worth noting that the metal mesh does not influence the attachment process very much. There are no upward leaders initiate from the mesh even when the downward leader hit directly on it. However, in one case there are unsuccessful upward leaders from the mesh close to successful connecting 
leader from the receptor (Fig. 7). The mesh doesn't influence the attachment points under the positive impulse, either.

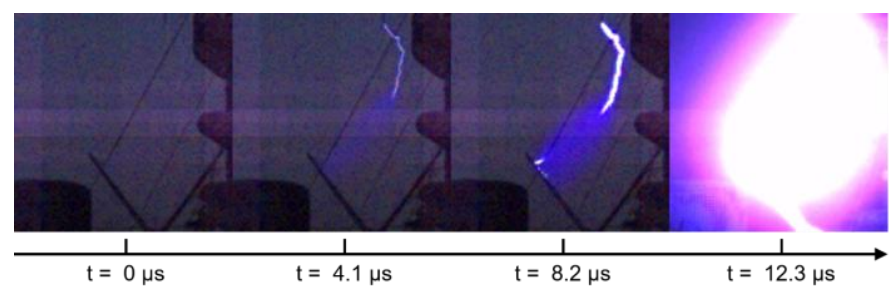

Figure 7. Unsuccessful upward leader from metal mesh under positive impulse $(\mathrm{LD}=1.8 \mathrm{~m})$.

One of the reasons why metal mesh seldom initiates the upward leader is that it provides no sharp point with small curvature radius compared with tip receptor. Another one is that there is a thin layer of GFRP outside the mesh, which may block the inception of the corona / streamer.

\section{Comparation between CFRP and GFRP WT blade}

From both GFRP and CFRP blade experiment results, the tip receptor provides pretty good protection for the blade. Some experiment work with much smaller gap $(0.35 \mathrm{~m})$ shows that the tip receptor or metal cap may fail to intercept the downward leader [6]. However, when the gap is much larger, in this paper from 1.5 to $3 \mathrm{~m}$, the tip receptor shows good performance.

The positive downward leaders are more difficult to be intercepted by the tip receptor, especially when it propagates indirectly above the blade or the orientation of the blade is close to horizontal. The difference is that, for CFRP blade, the damage caused by lightning strike hitting on the blade surface directly can be reduced due to the grounded metal mesh.

\section{SUMMARY}

From the experiment results, it is difficult for upward leader to initiate from metal mesh under both negative and positive impulses. The metal mesh has little influence on the attachment process. The metal mesh may provide extra protection for the condition that the lightning strike hits on the blade surface directly when the receptor fails to intercept the downward leader.

One question is that, for CFRP blade with conductive beam through the whole blade, is it still reasonable to use only the blade tip to test the performance of the LPS? As far as the experiment results indicate, the performance of tip receptor is positive.

Although the positive lightning strikes represent only $1 / 10$ of the whole CGs, the existing LPS cannot provide enough protection against it. How to improve the receptor (e.g. shape or position) to initiate the upward leader more efficiently remain to be studied.

\section{REFERENCES}

[1] N. J. Vasa, T. Naka, S. Yokoyama, A. Wada, A. Asakawa, and S. Arinaga, "Experimental study on lightning attachment manner considering various types of lightning protection measures on wind turbine blades," in Proc. ICLP, Kanazawa, Japan, 2006, pp. 1483-1487.

[2] S. Arinaga, "Experimental study on lightning protection methods for wind turbine blades," in Proc. ICLP, Kanazawa, Japan, 2006, pp. 1493 1496.

[3] T. Shindo, A. Asakawa, and M. Miki, "A study of lightning striking characteristics of wind turbines," in Proc. ICLP, Uppsala, Sweden, 2008, pp. 1-9.

[4] J. Montañá, V. March, B. Hermoso, and J. R. Hermoso, "High-speed videos of laboratory leaders emerging from wind turbine blade tips," in Proc. ICLP, Cagliari, Italy, 2010, pp. 1280-1-1280-5.

[5] S. Yokoyama, "Lightning protection of wind turbine blades," Electr. Power Syst. Res., vol. 94, pp. 3-9, Jan. 2013.

[6] A. M. Abd-Elhady, N. A. Sabiha, and M. A. Izzularab, "Experimental evaluation of air-termination systems for wind turbine blades," Electr. Power Syst. Res., vol. 107, pp. 133-143, Feb. 2014.

[7] Z. Guo, Q. Li, Y. Ma, et al, "Experimental study on lightning attachment manner to wind turbine blades with lightning protection system," IEEE Transactions on Plasma Science, 2018 (early access).

[8] Y. Ma, Z. Guo, Q. Li, J. Yan, H. Ren, and Y. Xiao, "Processing of upward leader on the wind turbine blade and critical length inception criterion," in Proc. ICLP, Estoril, Portugal, Sep. 2016, pp. 1-5.

[9] Z. Guo, Q. Li, W. Yu, W. Arif, Y. Ma and W. H. Siew, "Experimental study on lightning attachment manner to rotation wind turbine blade," in Proc. 34th ICLP, Rzeszow, Poland, 2018, pp. 1-5. 